\title{
Population structure and reproduction of Calanus helgolandicus (Copepoda, Calanoida) along the Iberian and Moroccan slope
}

\author{
S. Stöhr* , K. Schulz ${ }^{1 *} \&$ H.-Ch. John* \\ Zoologisches Institut und Museum der Universität Hamburg; \\ Martin-Luther-King-Platz 3, D-20146 Hamburg, Germany
}

\begin{abstract}
During three cruises, carried out in March 1991, October 1991, and January 1992 off the Iberian Peninsula and Morocco, the abundant calanoid copepod Calanus helgolandicus (Claus) was collected from a depth of $1000 \mathrm{~m}$ to the surface. Differences in depth preference were correlated with the life stage and geographically differing vertical salinity structures. In autumn and winter, only stage V copepodids (CV) and adults were found, in spring also younger copepodid stages. Within the range of the Mediterranean outflow water (MOW), a sharp decline of abundances of all stages was evident during all cruises. In autumn 1991, the bulk of the population was recorded south of the MOW, in winter 1992 north of it. During winter, numbers had declined by $70 \%$, supporting the idea that winter individuals represent the same generation as was encountered in autumn, and that they had been transported northwards. CV stages preferred the depth layer $400-800 \mathrm{~m}$, in autumn and winter. Adults were found in autumn at the same depth south of the MOW, while they preferred the 0-400 m layers north of it. In winter, the abundance of adults increased, males preferred the $400-600 \mathrm{~m}$ depth layer, while females stayed at 200-400 m. In spring 1991, stages younger than CV were found in high densities, all stages concentrating in the upper $200 \mathrm{~m}$. During the crossslope survey in spring off Portugal, an absolute abundance maximum of females was found. In contrast, offshore densities were very low. On the basis of these findings, the hypothesis of a Mediterranean centre of distribution and dispersal into the Atlantic is questioned. It is suggested that a separate, reproductively active population of $C$. helgolandicus exists off NW. Africa.
\end{abstract}

\section{INTRODUCTION}

A survey of the undercurrent off the Iberian Peninsula and Morocco was carried out; one biological subproject was based on the calanoid copepod species Calanoides carinatus (Krøyer) (Stöhr et al., in prep.). During this study the closely related species Calanus helgolandicus (Claus, 1863) was collected as well. Its distributional range covers the temperate Atlantic from off eastern N. America to the eastern boundary current system off Europe and NW. Africa, and the northern Mediterranean (Fleminger \& Hülsemann, 1977; Conover, 1988). Vertically, C. helgolandicus spans the depth range from $2000 \mathrm{~m}$ (Sargasso Sea) to the surface (Deevey \& Brooks, 1977). In spring, reproducing adults and young life

\footnotetext{
${ }^{1}$ Addressee for all correspondence

- Members of the Taxonomy Group at the Biologische Anstalt Helgoland
} 


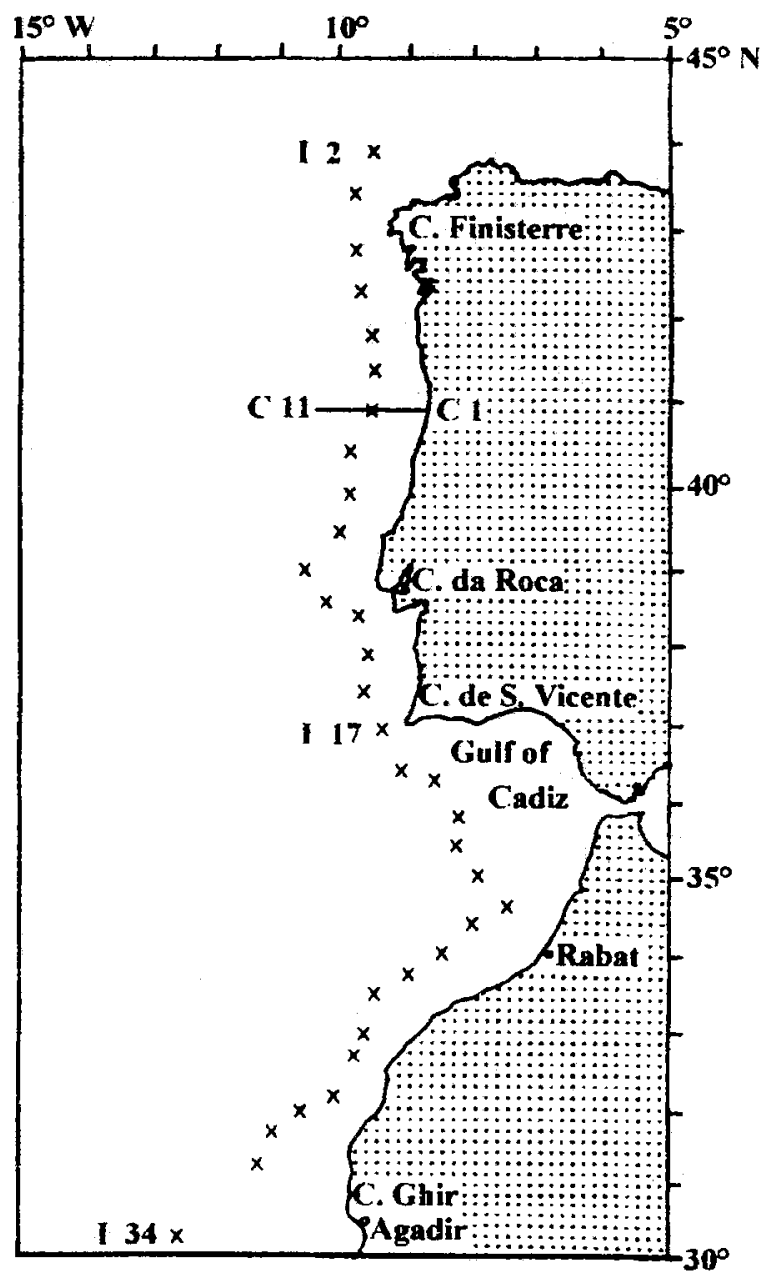

Fig. 1. Locations of sampling stations of "Heincke" cruises H09, H17, H20. Stations of the north-south transect along the $2000 \mathrm{~m}$ isobath indicated by " $\mathrm{x}$ " and numbers I 2-I 34, of the cross-slope transect off Portugal by horizontal line and C 1-C 11

stages dwell at subsurface depth (Williams \& Conway, 1988; Green et al., 1993). The overwintering copepodid stage CV is found below $400 \mathrm{~m}$ (Brenning, 1981; Williams \& Conway, 1988). Fleminger \& Hülsemann (1977) proposed up to three reproductively active populations of $C$. helgolandicus in the Atlantic: off temperate NE. America, in the North Sea and off NW. Africa, the latter to a certain degree in exchange with Mediterranean stocks by means of a subsurface outflow from the Mediterranean Sea and surface inflow from the Atlantic.

While the population dynamics and biology of C. helgolandicus in the northern part of the range of the species around the British Isles have been studied comparatively well (Williams, 1985; Williams \& Conway, 1988; Green et al., 1993), data for the southern part 
Table 1. Geographical positions of the standard isobath-parallel stations shown in Figure 1. Stations at which the plankton samples utilized were collected during the individual cruises indicated by " $\mathrm{x}$ "

\begin{tabular}{|c|c|c|c|c|c|}
\hline $\begin{array}{l}\text { Project: } \\
\text { Cruise: } \\
\text { Date: }\end{array}$ & & & $\begin{array}{c}\text { EBC 1 } \\
\text { Heincke } 09 \\
\text { March } 1991\end{array}$ & $\begin{array}{c}\text { EBC } 3 \\
\text { Heincke } 17 \\
\text { Oct. } 1991\end{array}$ & $\begin{array}{c}\text { EBC } 4 \\
\text { Heincke } 20 \\
\text { Jan. } 1992\end{array}$ \\
\hline Iso.- & \multicolumn{2}{|c|}{ Position } & & & \\
\hline Sta. & Latitude & Longitude & & & \\
\hline I 2 & $43^{\circ} 53^{\prime} \mathrm{N}$ & $09^{\circ} 33^{\prime} \mathrm{W}$ & $\mathrm{x}$ & & $\mathrm{x}$ \\
\hline 13 & $43^{\circ} 27^{\prime} \mathrm{N}$ & $09^{\circ} 52.5^{\prime} \mathrm{W}$ & $\mathrm{x}$ & & $\mathbf{x}$ \\
\hline I 4 & $42^{\circ} 50^{\prime} \mathrm{N}$ & $09^{\circ} 51^{\prime} \mathrm{W}$ & $x$ & & $\mathrm{x}$ \\
\hline I 5 & $42^{\circ} 17.5^{\prime} \mathrm{N}$ & $09^{\circ} 44^{\prime} \mathrm{W}$ & $\mathrm{x}$ & & $\mathrm{x}$ \\
\hline I 6 & $41^{\circ} 50^{\prime} \mathrm{N}$ & $09^{\circ} 38^{\prime} \mathrm{W}$ & $\mathrm{x}$ & & $\mathbf{x}$ \\
\hline 17 & $41^{\circ} 22^{\prime} \mathrm{N}$ & $09^{\circ} 34^{\prime} \mathrm{W}$ & $\mathrm{x}$ & & $x$ \\
\hline I 8 & $40^{\circ} 53^{\prime} \mathrm{N}$ & $09^{\circ} 36.5^{\prime} \mathrm{W}$ & $\mathrm{x}$ & & $\mathrm{x}$ \\
\hline I 9 & $40^{\circ} 23.5^{\prime} \mathrm{N}$ & $09^{\circ} 52^{\prime} \mathrm{W}$ & $\mathrm{x}$ & & $\mathrm{x}$ \\
\hline I 10 & $39^{\circ} 53^{\prime} \mathrm{N}$ & $09^{\circ} 54.5^{\prime} \mathrm{W}$ & $\mathrm{x}$ & & $\mathrm{x}$ \\
\hline I 11 & $39^{\circ} 26^{\prime} \mathrm{N}$ & $10^{\circ} 07^{\prime} \mathrm{W}$ & $\mathrm{x}$ & $\mathrm{x}$ & $\mathbf{x}$ \\
\hline I 12 & $39^{\circ} 00^{\prime} \mathrm{N}$ & $10^{\circ} 38^{\prime} \mathrm{W}$ & $\mathrm{x}$ & $\mathrm{x}$ & $\mathrm{x}$ \\
\hline I 13 & $38^{\circ} 42^{\prime} \mathrm{N}$ & $10^{\circ} 17^{\prime} \mathrm{W}$ & $\mathrm{x}$ & $\mathrm{x}$ & $\mathrm{x}$ \\
\hline I 14 & $38^{\circ} 27^{\prime} \mathrm{N}$ & $09^{\circ} 47^{\prime} \mathrm{W}$ & $\mathrm{x}$ & $\mathrm{x}$ & $\mathrm{x}$ \\
\hline I 15 & $37^{\circ} 57^{\prime} \mathrm{N}$ & $09^{\circ} 39^{\prime} \mathrm{W}$ & $\mathrm{x}$ & $\mathrm{x}$ & $\mathrm{x}$ \\
\hline I 16 & $37^{\circ} 25^{\prime} \mathrm{N}$ & $09^{\circ} 42^{\prime} \mathrm{W}$ & $\mathrm{x}$ & $\mathrm{x}$ & $\mathrm{x}$ \\
\hline I 17 & $36^{\circ} 59^{\prime} \mathrm{N}$ & $09^{\circ} 22^{\prime} \mathrm{W}$ & & $\mathrm{x}$ & $\mathrm{x}$ \\
\hline I 18 & $36^{\circ} 30^{\prime} \mathrm{N}$ & $09^{\circ} 04.5^{\prime} \mathrm{W}$ & & $\mathrm{x}$ & $\mathrm{x}$ \\
\hline I 19 & $36^{\circ} 19^{\prime} \mathrm{N}$ & $08^{\circ} 35.5^{\prime} \mathrm{W}$ & & $\mathrm{x}$ & $\mathrm{x}$ \\
\hline I 20 & $35^{\circ} 35.5^{\prime} \mathrm{N}$ & $08^{\circ} 13^{\prime} \mathrm{W}$ & & $\mathrm{x}$ & $\mathrm{x}$ \\
\hline I 21 & $35^{\circ} 25.5^{\prime} \mathrm{N}$ & $08^{\circ} 13^{\prime} \mathrm{W}$ & & $\mathrm{x}$ & $\mathrm{x}$ \\
\hline I 22 & $35^{\circ} 00^{\prime} \mathrm{N}$ & $07^{\circ} 55^{\prime} \mathrm{W}$ & & $\mathrm{x}$ & $\mathrm{x}$ \\
\hline I 23 & $34^{\circ} 39^{\prime} \mathrm{N}$ & $07^{\circ} 29.5^{\prime} \mathrm{W}$ & & $\mathrm{x}$ & $\mathrm{x}$ \\
\hline I 24 & $34^{\circ} 21^{\prime} \mathrm{N}$ & $07^{\circ} 58.5^{\prime} \mathrm{W}$ & & $\mathrm{x}$ & $\mathrm{x}$ \\
\hline I 25 & $34^{\circ} 03^{\prime} \mathrm{N}$ & $08^{\circ} 27^{\prime} \mathrm{W}$ & & $\mathrm{x}$ & $\mathrm{x}$ \\
\hline 126 & $33^{\circ} 49^{\prime} \mathrm{N}$ & $08^{\circ} 58^{\prime} \mathrm{W}$ & & $\mathrm{x}$ & $\mathrm{x}$ \\
\hline I 27 & $33^{\circ} 34^{\prime} \mathrm{N}$ & $09^{\circ} 29^{\prime} \mathrm{W}$ & & $\mathrm{x}$ & $\mathrm{x}$ \\
\hline I 28 & $33^{\circ} 06^{\prime} \mathrm{N}$ & $09^{\circ} 34^{\prime} \mathrm{W}$ & & $\mathrm{x}$ & $x$ \\
\hline I 29 & $32^{\circ} 43^{\prime} \mathrm{N}$ & $09^{\circ} 48.5^{\prime} \mathrm{W}$ & & $\mathrm{x}$ & $\mathrm{x}$ \\
\hline I 30 & $32^{\circ} 16^{\prime} \mathrm{N}$ & $10^{\circ} 05^{\prime} \mathrm{W}$ & & $\mathrm{x}$ & $\mathrm{x}$ \\
\hline I 31 & $32^{\circ} 00^{\prime} \mathrm{N}$ & $10^{\circ} 35.5^{\prime} \mathrm{W}$ & & $\mathrm{x}$ & $\mathrm{x}$ \\
\hline I 32 & $31^{\circ} 42.5^{\prime} \mathrm{N}$ & $11^{\circ} 00^{\prime} \mathrm{W}$ & & $\mathrm{x}$ & $\mathrm{x}$ \\
\hline I 33 & $31^{\circ} 15^{\prime} \mathrm{N}$ & $11^{\circ} 18^{\prime} \mathrm{W}$ & & $\mathrm{x}$ & \\
\hline 134 & $30^{\circ} 17^{\prime} \mathrm{N}$ & $12^{\circ} 33^{\prime} \mathrm{W}$ & & $\mathrm{x}$ & \\
\hline
\end{tabular}

of the range are scarce. Furthermore, most of the earlier studies were restricted to the upper $200 \mathrm{~m}$ of the water column or even shallower, whereas during this survey a depth of $1000 \mathrm{~m}$ was sampled in discrete layers. The special environmental conditions given by the outflow of Mediterranean high-salinity water into the East Atlantic Ocean through the Strait of Gibraltar (sill depth ca $200-320 \mathrm{~m}$ ) provide an opportunity to study the ecological reaction of C. helgolandicus and to recognize possible ways of transport and distribution. Seasonal changes in the age composition of the population offer clues to the understanding of annual population dynamics. 
Table 2. The cross-slope stations of project EBC 1 (Heincke 09, March 1991), shown in Figure 1. Bottom depth equals fishing depth at stations $\mathrm{C} 1-\mathrm{C} 6$; at $\mathrm{C} 7-\mathrm{C} 11$ maximum depth sampled was $1000 \mathrm{~m}$

\begin{tabular}{|c|c|c|c|}
\hline $\begin{array}{l}\text { Cross- } \\
\text { slope } \\
\text { station }\end{array}$ & Latitude & Longitude & $\begin{array}{c}\text { Bottom } \\
\text { depth } \\
\text { [m] }\end{array}$ \\
\hline C 1 & $40^{\circ} 50^{\prime} \mathrm{N}$ & $08^{\circ} 45^{\prime} \mathrm{W}$ & 24 \\
\hline C 2 & $40^{\circ} 50^{\prime} \mathrm{N}$ & $08^{\circ} 51^{\prime} \mathrm{W}$ & 41 \\
\hline C 3 & $40^{\circ} 50^{\prime} \mathrm{N}$ & $08^{\circ} 57.5^{\prime} \mathrm{W}$ & 60 \\
\hline C 4 & $40^{\circ} 50^{\prime} \mathrm{N}$ & $09^{\circ} 05.5^{\prime} \mathrm{W}$ & 103 \\
\hline C 5 & $40^{\circ} 50^{\prime} \mathrm{N}$ & $09^{\circ} 12.3^{\prime} \mathrm{W}$ & 136 \\
\hline C 6 & $40^{\circ} 50^{\prime} \mathrm{N}$ & $09^{\circ} 19^{\prime} \mathrm{W}$ & 209 \\
\hline C 7 & $40^{\circ} 50^{\prime} \mathrm{N}$ & $09^{\circ} 26^{\prime} W$ & 1448 \\
\hline $\mathrm{C} 8$ & $40^{\circ} 50^{\prime} \mathrm{N}$ & $09^{\circ} 32.5^{\prime} \mathrm{W}$ & 2652 \\
\hline C 9 & $40^{\circ} 50^{\prime} \mathrm{N}$ & $09^{\circ} 42.5^{\prime} \mathrm{W}$ & 3038 \\
\hline C 10 & $40^{\circ} 50^{\prime} \mathrm{N}$ & $09^{\circ} 52.5^{\prime} \mathrm{W}$ & 3302 \\
\hline C 11 & $40^{\circ} 50^{\prime} \mathrm{N}$ & $10^{\circ} 12^{\prime} \mathrm{W}$ & 3620 \\
\hline
\end{tabular}

\section{MATERIAL AND METHODS}

Sampling was carried out during three cruises of RV "Heincke" in March 1991 (H09), October 1991 (H17), and January 1992 (H20) as part of a multidisciplinary research project within the World Ocean Circulation Experiment (WOCE). Tables 1 and 2 present the standardized station numbers for the three cruises, station locations and dates. Figure 1 shows the "Isobath" stations I $2-134$ following approximately the $2000 \mathrm{~m}$ isobath along the slopes of the Iberian Peninsula and northern Morocco, and the cross-slope stations C 1 - C 11 off northern Portugal (in spring of 1991). Except at the shallow shelf stations (Table 2), plankton was sampled vertically from $1000 \mathrm{~m}$ to the surface in $200 \mathrm{~m}$ steps using a multiple-opening-closing net (MUV) of $300 \mu \mathrm{m}$ mesh size, hauled vertically (Weikert \& John, 1981). Additional sampling was carried out with a neuston net (NEU) of the same mesh size (Hempel \& Weikert, 1972), roughly filtering the upper $25 \mathrm{~cm}$ of the water column (upper and lower nets combined). At each station a vertical tow of five stratified hauls and a neuston tow were made. The samples were preserved in $4 \%$ buffered Formaldehyde solution immediately after capture and completely sorted for Calanus helgolandicus, separating both sexes (according to Fleminger \& Hülsemann, 1977) and the copepodid stages V, IV and $\leq$ III. Since early copepodids ( $\leq \mathrm{CIV}$ ) of C. helgolandicus cannot be distinguished from those of Calanus finmarchicus by morphological characteristics alone, young copepodids of the former species were considered only from those stations at which no C. finmarchicus (CV or adult) were found. Nevertheless, some doubts remain about the exact identification of the early stages, particularly at the isobath stations off northern Portugal where almost certainly CIV of both species co-occurred. These early stages were therefore excluded from the analysis.

The numbers of individuals of each sex or stage per $200 \mathrm{~m}$ stratum or per neuston sample were quantified to abundance values $n / 1 \mathrm{~m}^{2}$ (MUV) or $n / 1000 \mathrm{~m}^{2}$ (NEU) respectively, closest to the actually sampled areas (on average $0.26 \mathrm{~m}^{2}\left[0.02 \mathrm{SD}\right.$ ] and $574.5 \mathrm{~m}^{2}$ [43.7 SD], for $384 \mathrm{MUV}$ samples and 83 NEU tows, respectively), admitting some corrections for wire angle deviations. (Readers who are more familiar with $\mathrm{n} / \mathrm{m}^{3}$ may divide our 


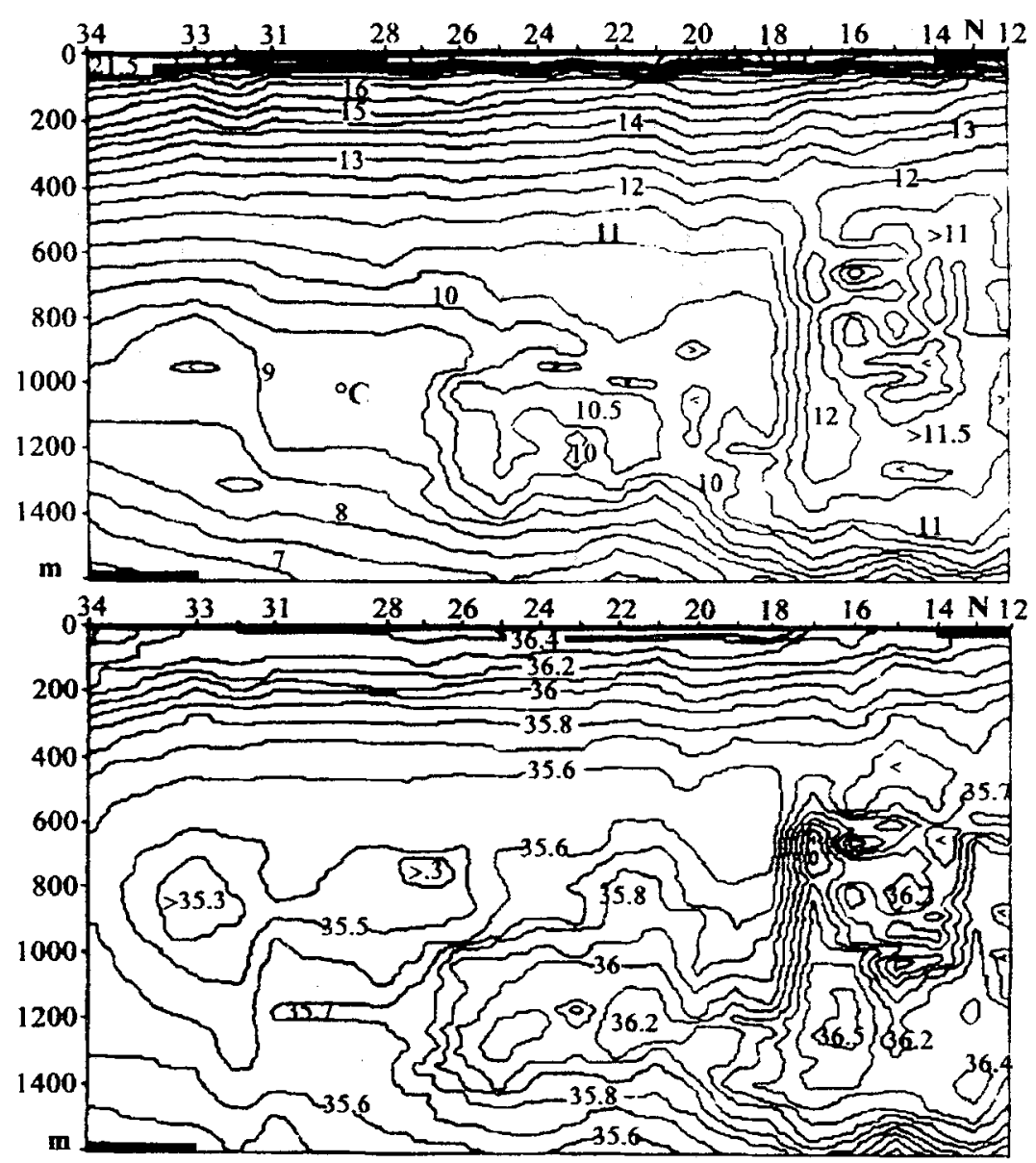

Fig. 2. Temperature $\left({ }^{\circ} \mathrm{C}\right.$, top) and salinity ( $\mathrm{S}$, bottom) conditions during "Heincke" cruise $\mathrm{H} 17$ in autumn 1991, north-south transect with north to the right, station numbers indicated on top of the plots

MUV data by 200.) Abundance values calculated for the isobath transects were smoothed by moving averages over 3 values, since plankton data are inadvertently noisy, possibly due to patchiness. However, species abundances of the cross-slope transect were not averaged because hydrographical conditions and bottom depth differed substantially between stations, thus possibly affecting the plankton distribution to a considerable extent.

\section{RESULTS}

The data are presented here in the natural sequence of the seasons rather than in the sequence of the cruises. Detailed descriptions of the hydrographic conditions will be given by Stöhr et al. (in prep.). The most interesting feature of the hydrographic data in this region is the range and spreading of Mediterranean outflow water (MOW) into the eastern Atlantic. During all cruises, recorded numbers of individuals were not correlated with the hour of capture. 


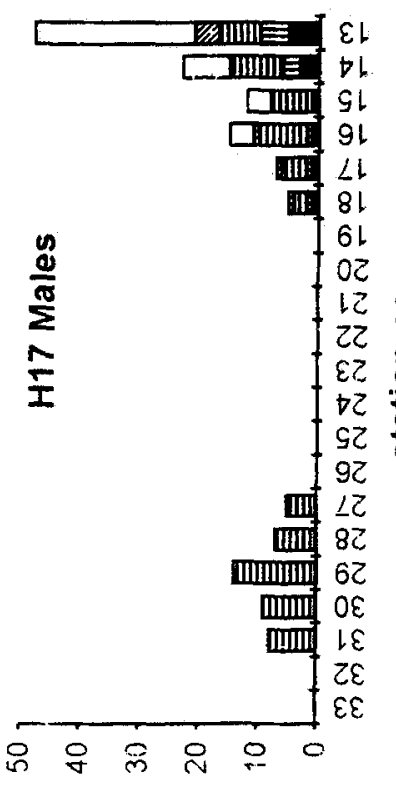

$z^{\mathrm{w} / \mathrm{u}}$

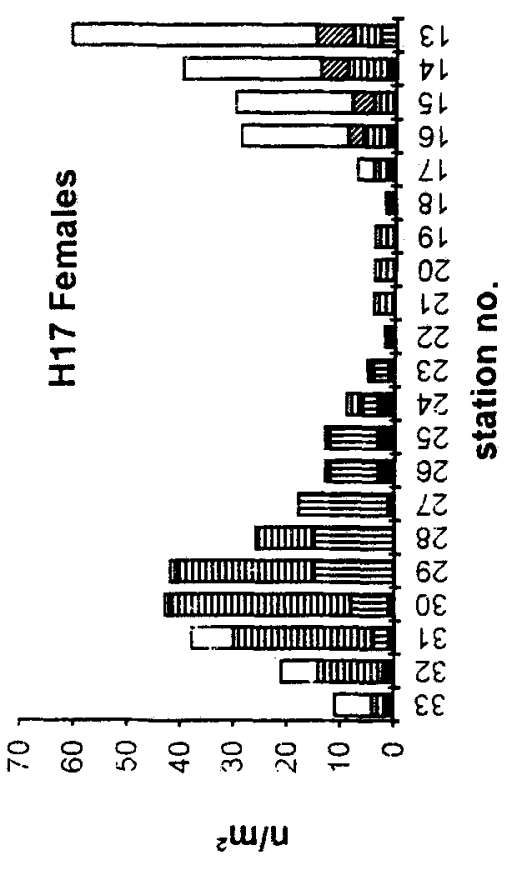

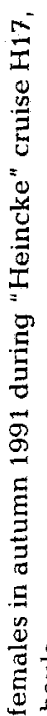

풍

点

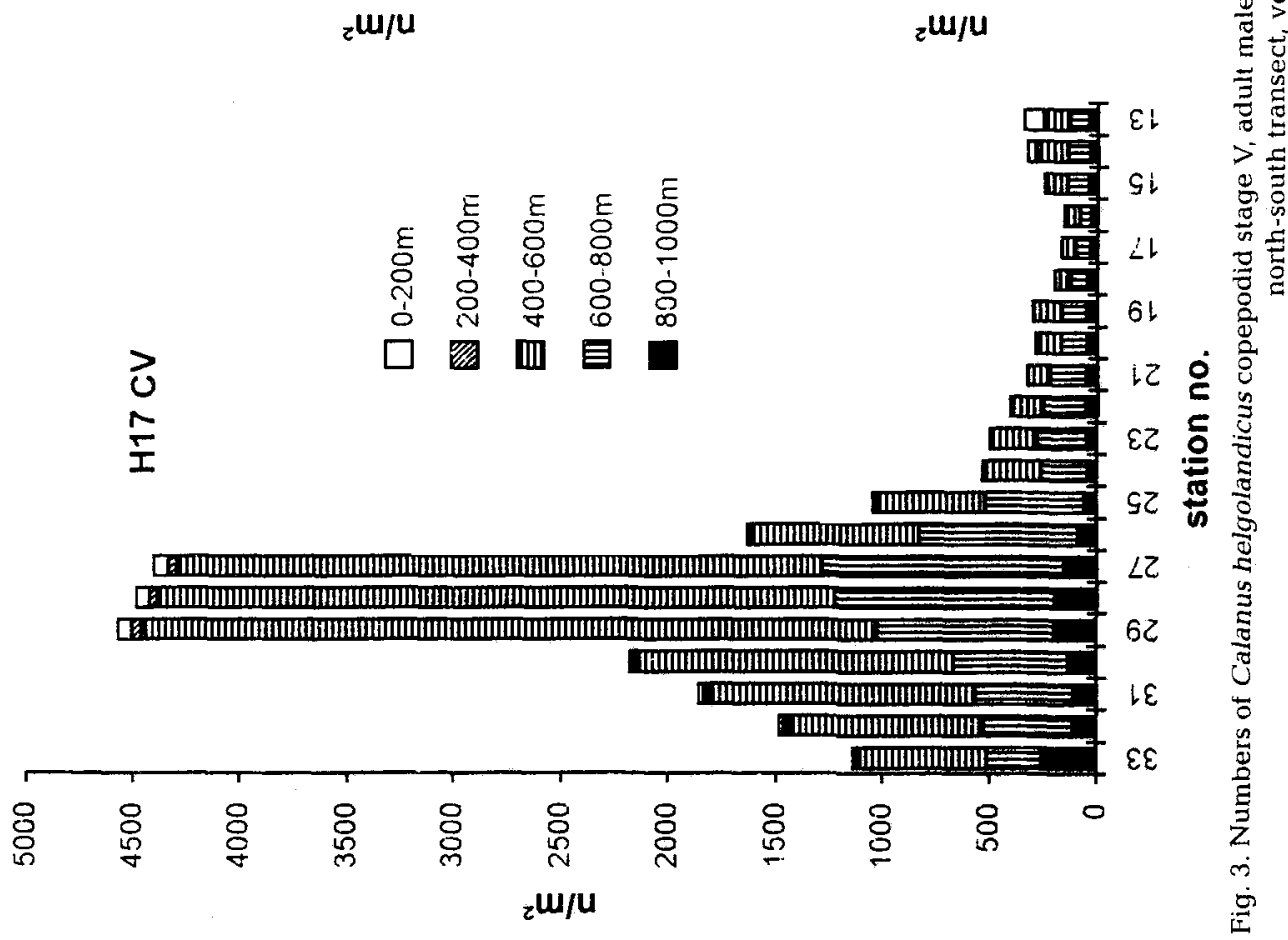




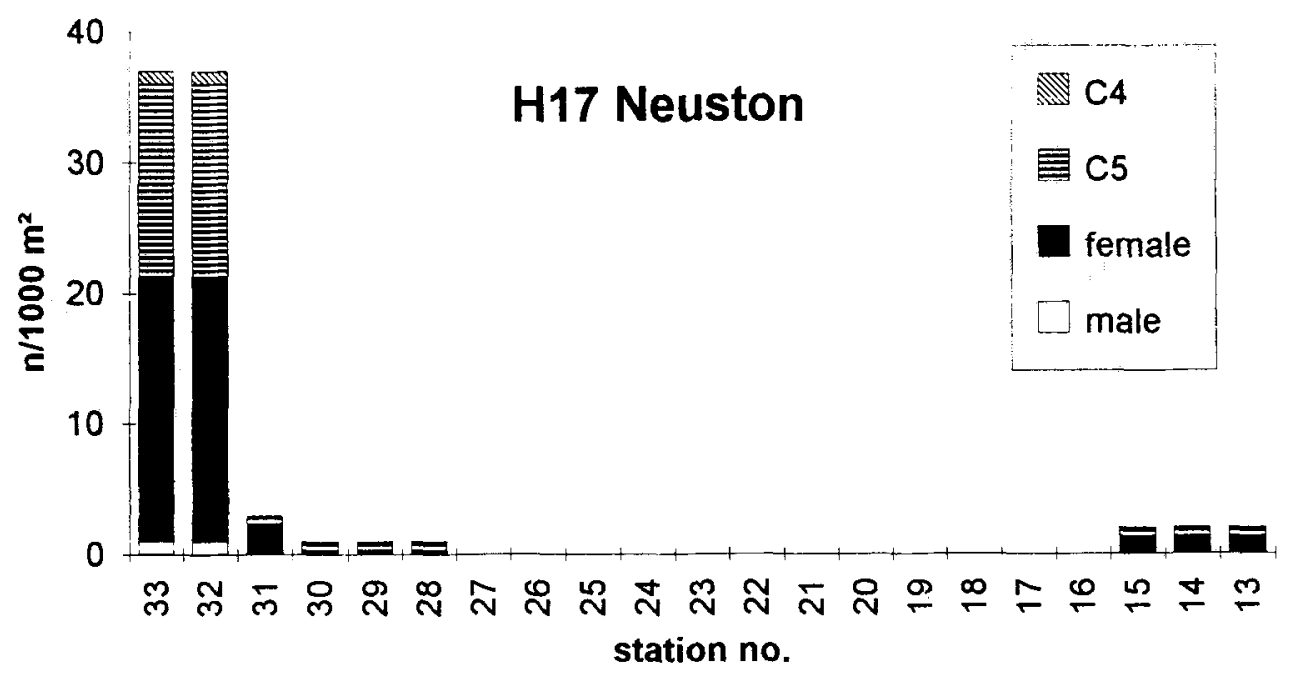

Fig. 4. Surface numbers of adult males and females, and copepodids V of Calanus helgolandicus in winter 1991 during "Heincke" cruise H17, north-south transect

\section{Autumn}

\section{Vertical hauls}

In autumn 1991 (Cruise H17) the range of MOW in the Atlantic extended southward as far as station 127 (Fig. 2) at depths of $800-1000 \mathrm{~m}$, with temperatures around $10^{\circ} \mathrm{C}$ and salinities (S) up to 35.8. However, the main current of MOW stretched northwards, reaching a depth of approximately $500 \mathrm{~m}$ at station I 17 , with temperatures up to $12{ }^{\circ} \mathrm{C}$ and $\mathrm{S}=36.3$, down to the deepest layer sampled.

The population of Calanus helgolandicus consisted mainly of stage $\mathrm{V}$ copepodids (CV), besides few male and female adults (Fig. 3). CV numbers increased northwards with maximum concentrations up to 4500 ind. $/ \mathrm{m}^{2}$ (stations I 27-29). From station I 26 onwards, numbers decreased substantially, with minimum values at station I 16, amounting to less than $5 \%$ of the maximum. Northwards, abundances rose again but only slightly. This significant numerical minimum was also true for adults of both sexes and coincided with the area influenced by the MOW. Late copepodids as well as males and females were found to dwell mainly in the $400-600 \mathrm{~m}$ layer, with nearly $50 \%$ of the CV population occurring at this depth. South of the area influenced by the MOW nearly all adults occurred below $400 \mathrm{~m}$; no males and only a few females were found in the area of the MOW. Adult abundance increased again north of the MOW, the depth preference shifting to the upper $200 \mathrm{~m}$ for ca $30-50 \%$ of the males and $70 \%$ of the females. For this cruise the sex ratio of adults was $2: 1$ slightly in favour of females.

\section{Neuston hauls}

At the surface, numbers of C. helgolandicus were very low (Fig. 4). More than $50 \%$ of the specimens consisted of females, most of the rest of CV. Copepodid stages III and smaller were absent from the neuston layer. Males and CIV were collected only in single 


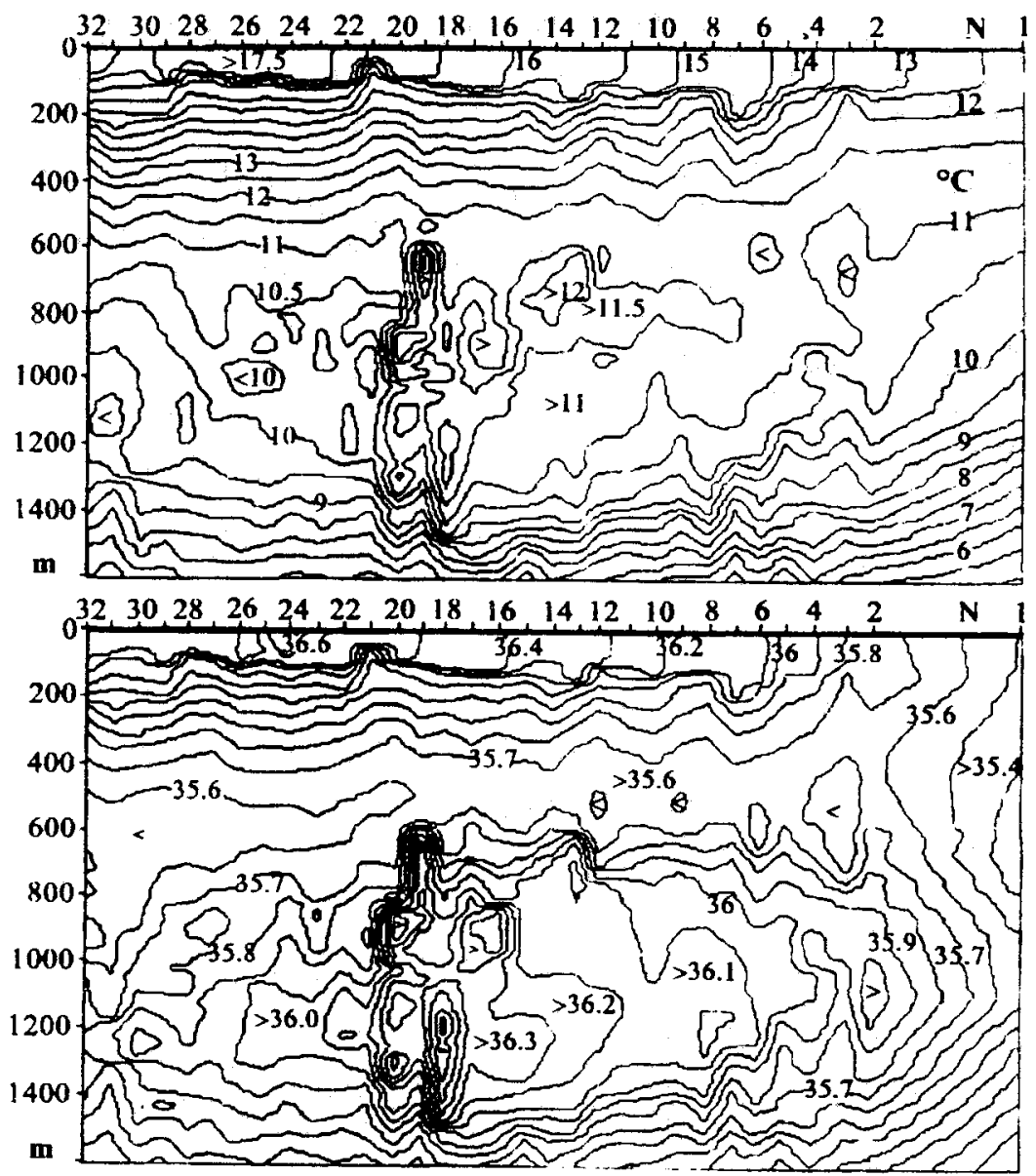

Fig. 5. Temperature $\left({ }^{\circ} \mathrm{C}\right.$, top) and salinity (S, bottom) conditions during "Heincke" cruise H20 in winter 1992, north-south transect with north to the right, station numbers indicated on top of the plots

numbers. Almost the entire population occurred at the southernmost stations I 32 and

I 33. In the area influenced by the MOW, C. helgolandicus was not found at all.

\section{Winter}

\section{Vertical hauls}

In winter 1992 (Cruise H20) the MOW remained below $600 \mathrm{~m}$ (Fig. 5). In the deepest layer sampled, its intrusion was traceable up to the northernmost stations. Average numbers of $\mathrm{CV}$ were only ca $11 \%$ of autumn maxima, whereas numbers of adults had doubled (Fig. 6). The area of minimum abundances was considerably restricted, compared to the autumn, and not as sharply pronounced. Approximately from station I 23 to I 20 , num- 


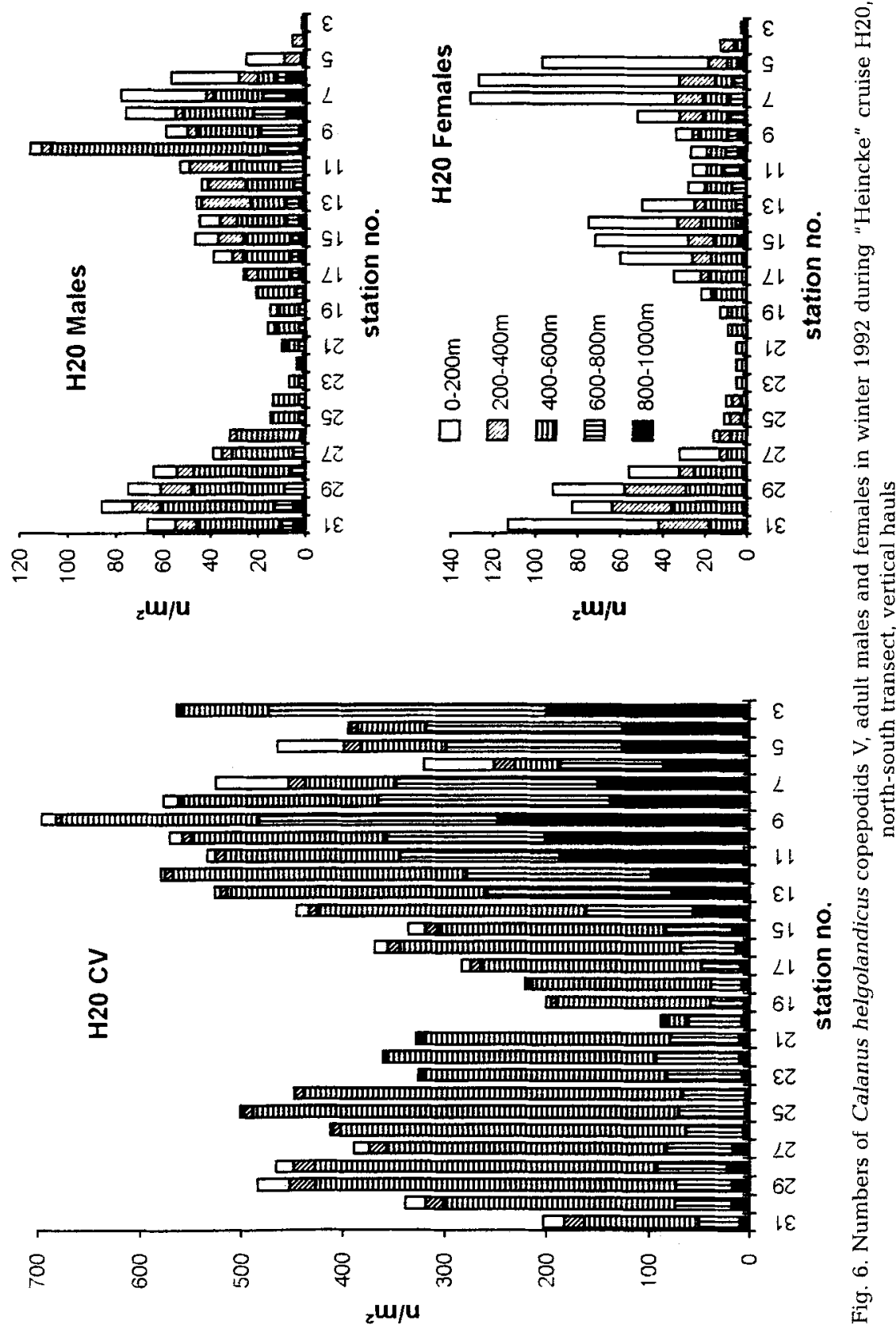




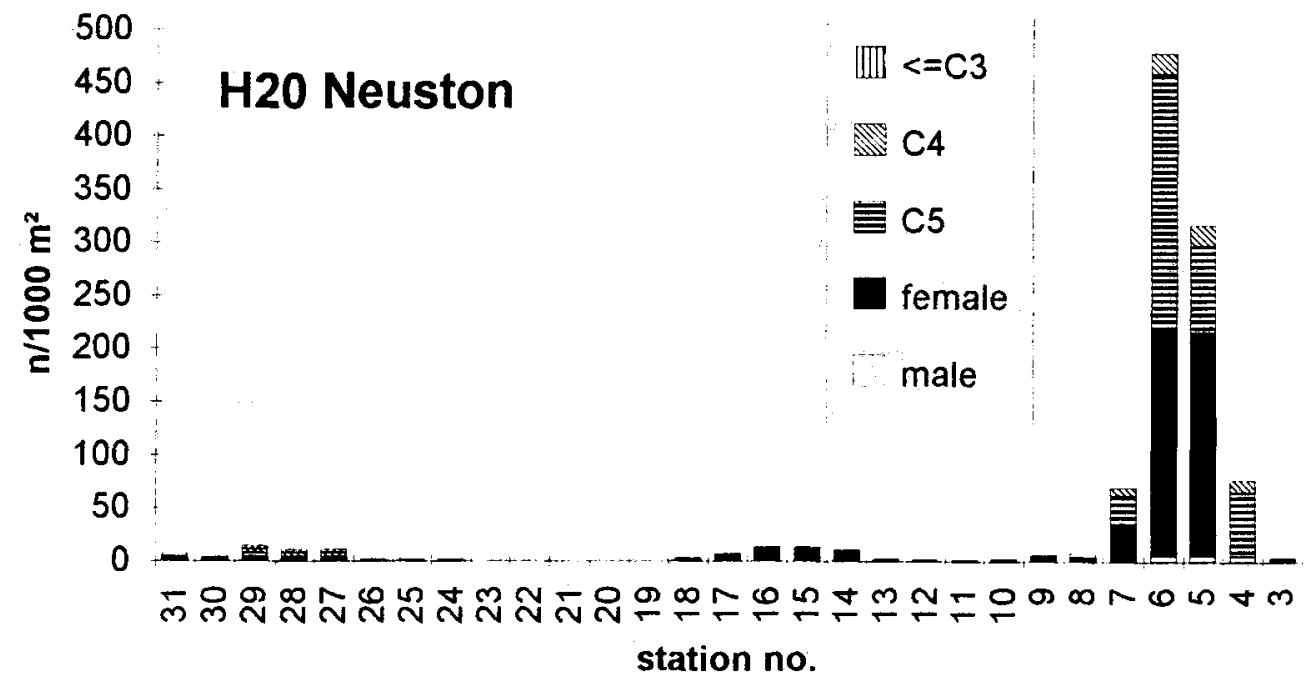

Fig. 7. Surface numbers of adult and copepodid stages of Calanus helgolandicus in winter 1992 during "Heincke" cruise H20, north-south transect

bers were distinctly low. Minimum values of CV (sta. I 20) were only about $20 \%$ of those of the southern maximum (sta. I 25). Northwards, abundances of CV and adults increased again, reaching higher densities than in the south. The depth distribution showed a preference of CV for the 400-600 m layer at the southern stations up to about station I 14. In the north the $\mathrm{CV}$ population was distributed with equal proportions between $400 \mathrm{~m}$ and $1000 \mathrm{~m}$; about $70 \%$ of the population were found deeper than $600 \mathrm{~m}$. Males preferred the layer of $400-600 \mathrm{~m}$ at all locations. Their numbers dropped pronouncedly north of station I 6. Females were distributed mainly from 0 to $600 \mathrm{~m}$ depth with at least $70 \%$ of them in the upper $400 \mathrm{~m}$. At stations I 7 to I $5 \mathrm{ca} 70 \%$ of them were found in the upper $200 \mathrm{~m}$. At the north-western edge of the Iberian Peninsula (stations I 4, I 3) abundance values declined to a further minimum. During the entire winter cruise, the sex ratio of adults was almost balanced at 1:1.

\section{Neuston hauls}

At the surface, contrary to the vertical hauls, considerable numbers of $C$. helgolandicus were found only in the north (stations I 4 - I 7, Fig. 7). Females were most abundant with CV following close second. Young copepodids were scarce and males almost absent.

\section{Spring}

\section{Isobath-parallel transect - vertical hauls}

In spring 1991 (Cruise H09), the intrusion of MOW was recognizable in the south below $600 \mathrm{~m}$; below $800 \mathrm{~m}$ it reached the northernmost stations (Fig. 8). Young copepodids were found in addition to $\mathrm{CV}$ and adults of both sexes (Fig. 9). Half of the population of C. helgolandicus consisted of CIII. All stages reached their abundance maximum south of station I 13 and almost the entire population was found in the upper $200 \mathrm{~m}$. At the nor- 


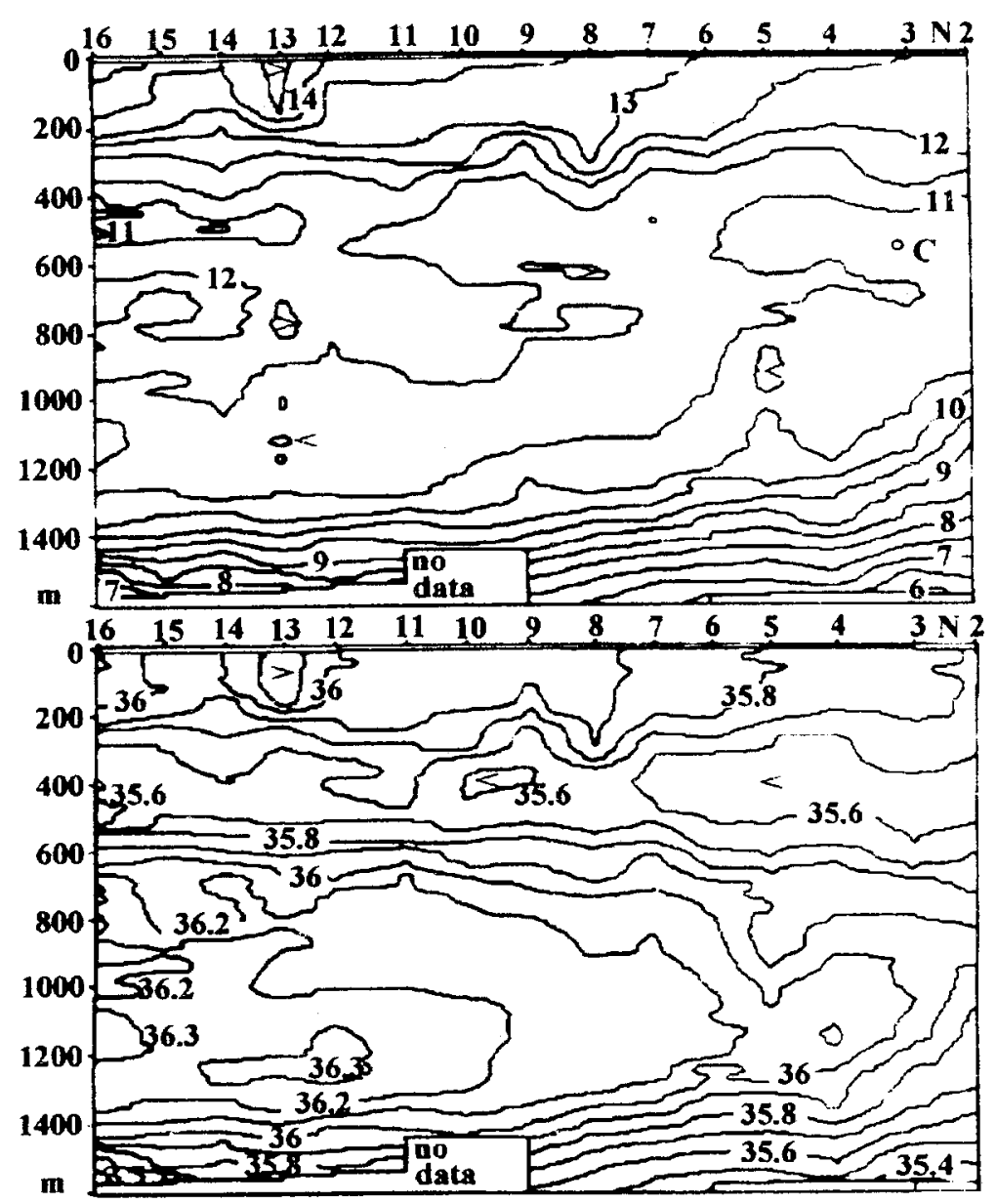

Fig. 8. Temperature $\left({ }^{\circ} \mathrm{C}\right.$, top) and salinity ( $\mathrm{S}$, bottom) conditions during "Heincke" cruise H09 in spring 1991, north-south transect, north to the right, station numbers on top of the plots

thern stations, only females were captured in significant numbers. The abundances of the remaining stages, including males, were minimal. Numbers of CIV and CV each amounted to about $30 \%$ of those of CIII. The sex ratio of adults was $2: 1$ in favour of females.

\section{Isobath-parallel transect - neuston hauls}

The neuston catches (Fig. 10) showed the highest abundances of all stages at the southernmost station, I 15, but maxima for females at stations I 9, I 10, and I 11. Abundances of CIV were higher than those of CIII. Almost no males were found.

\section{Cross-slope transect - vertical hauls}

Above the continental shelf, temperatures decreased slightly with increasing depth and distance from shore, whereas salinity increased (Fig. 11). Westwards of the shelf (sta. $\mathrm{C} 7-\mathrm{C} 11$ ) the water was well stratified with a salinity maximum in the $600-1400 \mathrm{~m}$ layer, 

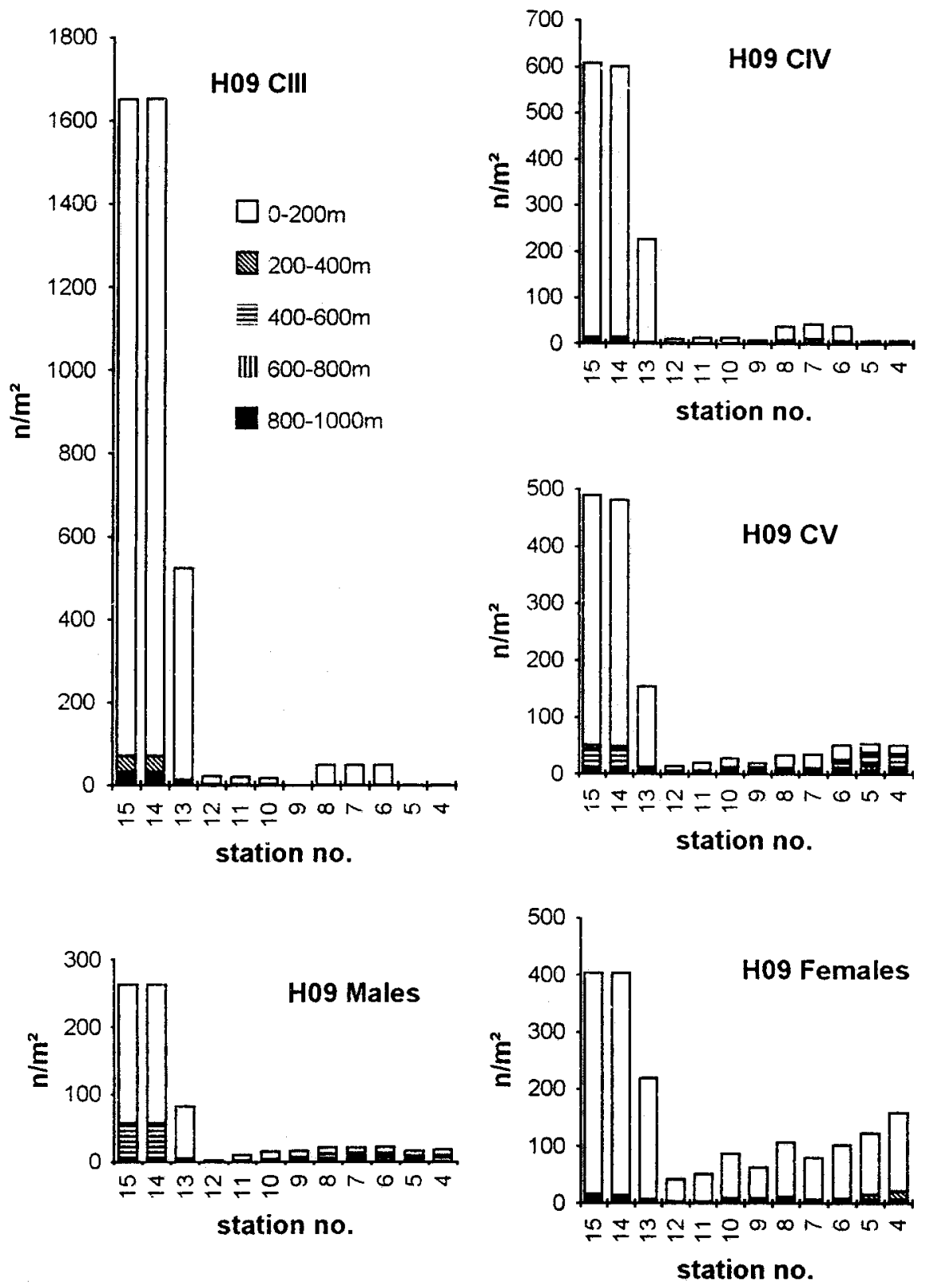

Fig. 9. Numbers of adult and copepodid stages of Calanus helgolandicus in spring 1991 during "Heincke" cruise $\mathrm{H09}$, north-south transect, vertical hauls 


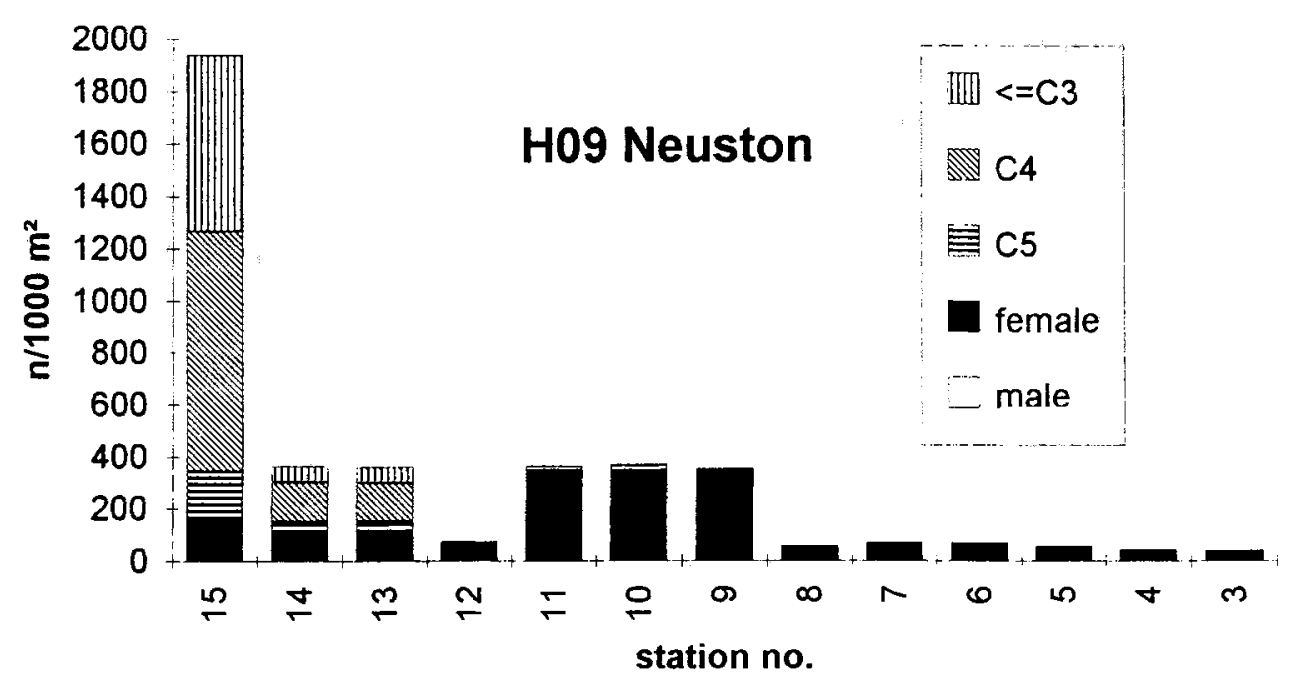

Fig. 10. Surface numbers of adult and copepodid stages of Calanus helgolandicus in spring 1991 during "Heincke" cruise H09, north-south transect.

representing the intrusion of MOW. Copepodid stages CIII -CV, as well as males and females occurred (Fig. 12). The highest numbers of all stages were observed above the shelf, with only minimal numbers towards the open sea. Abundances of females of all cruises peaked above the shelf. The sex ratio of adults was 9:1 strongly in favour of females. CV were caught in higher numbers than either CIV or CIII.

Cross-slope transect - neuston hauls

The neuston catches (Fig. 13) showed the same tendency as the vertical hauls with the bulk of the population occurring above the shelf. Here the highest abundances appeared above the deeper shelf at stations $\mathrm{C} 5$ and $\mathrm{C}$. Half of the population was composed of females. Almost no males were collected and CIII were likewise rare. Numbers of $\mathrm{CV}$ amounted to about $30 \%$ of those of females and numbers of CIV to $50-70 \%$ of those of CV.

\section{DISCUSSION}

In the Iberian-Moroccan region the changes in age composition and the population fluctuation patterns of $C$. helgolandicus correspond fairly well with the results of Green et al. (1993) obtained in the English Channel. There, peak abundances of this species in April corresponded with the onset of phytoplankton growth. In the Mediterranean Sea, Kouwenberg (1993) found highest densities of C. helgolandicus during February. Off Portugal, peak densities in March might represent the highest numerical values of the local population in the course of the year.

During the "Heincke" cruises, C. helgolandicus showed seasonal vertical migration. In autumn and winter the preferred depth stratum of the C. helgolandicus population (CV 


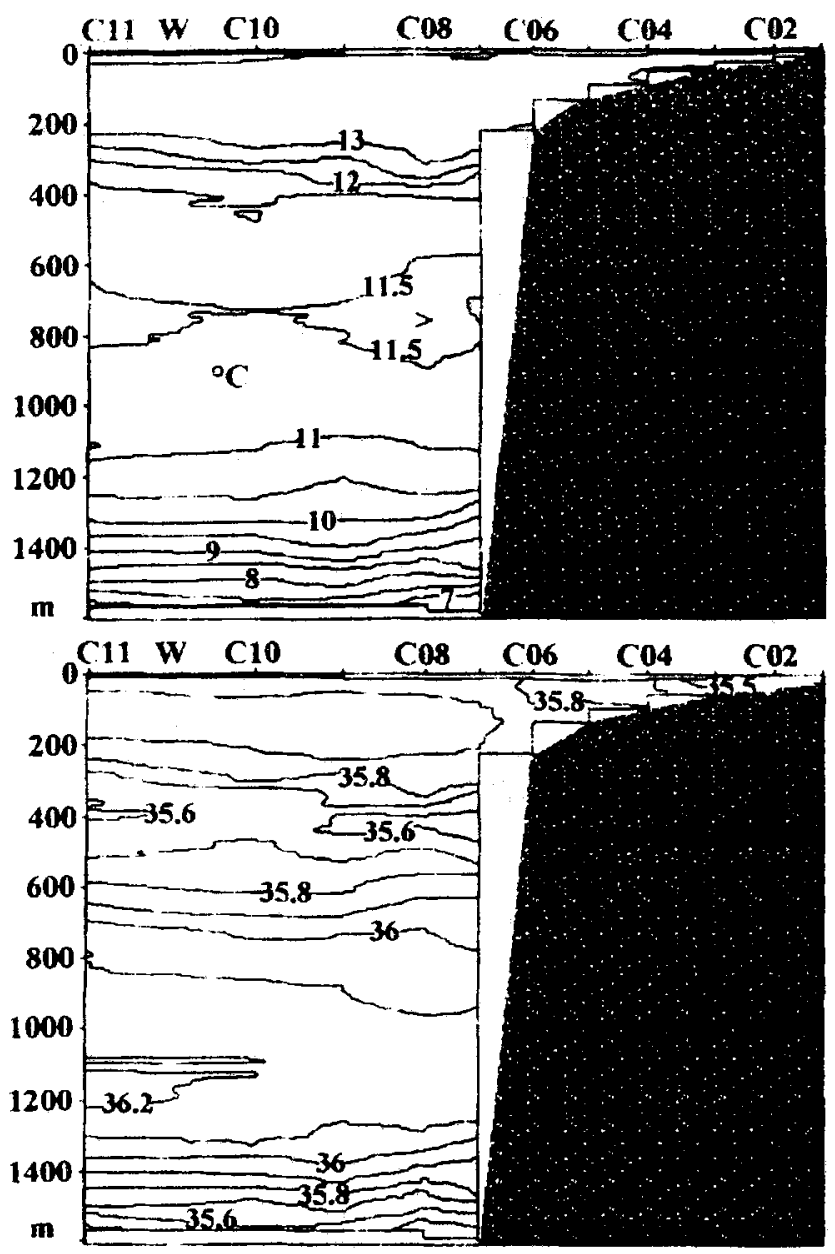

Fig. 11. Temperatures $\left({ }^{\circ} \mathrm{C}\right.$, top) and salinity ( $\mathrm{S}$, bottom) conditions during "Heincke" cruise H09 in spring 1991, cross-slope transect, west to the left, station numbers indicated on top of the plots

and adults) was $400-600 \mathrm{~m}$ south of the MOW and $400-800 \mathrm{~m}$ north of it. This is about $200 \mathrm{~m}$ shallower than in the closely related species Calanoides carinatus (Stöhr et al., in prep.), caught simultaneously. This depth preference is in accordance with Williams \& Conway (1988), who found overwintering CV of $C$. helgolandicus below $400 \mathrm{~m}$ depth to the south-west of the British Isles, whereas in spring all life stages occurred mainly in the upper $200 \mathrm{~m}$.

Brenning (1981) defined the salinity and temperature preferences of C. helgolandicus as being within the range of $\mathrm{S}=35.6-36.87$ and $15.75-20.2^{\circ} \mathrm{C}$. He characterized the species as adapted to warm temperate conditions, and as an indicator species for the Canary Current. In addition, $C$. helgolandicus shows high abundance in the Mediterranean Sea in adaptation to the high salinity there (Roe, 1972). Correspondingly, in the 

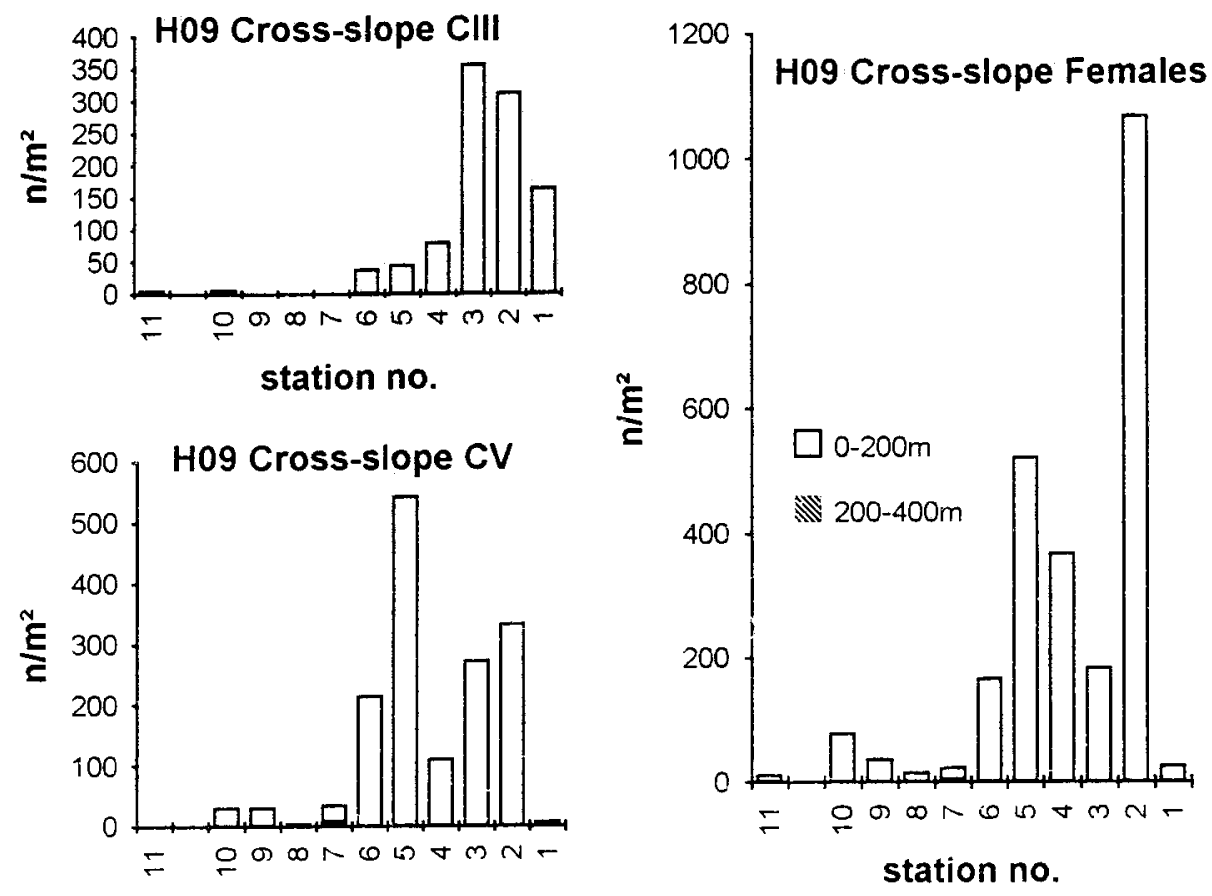

station no.
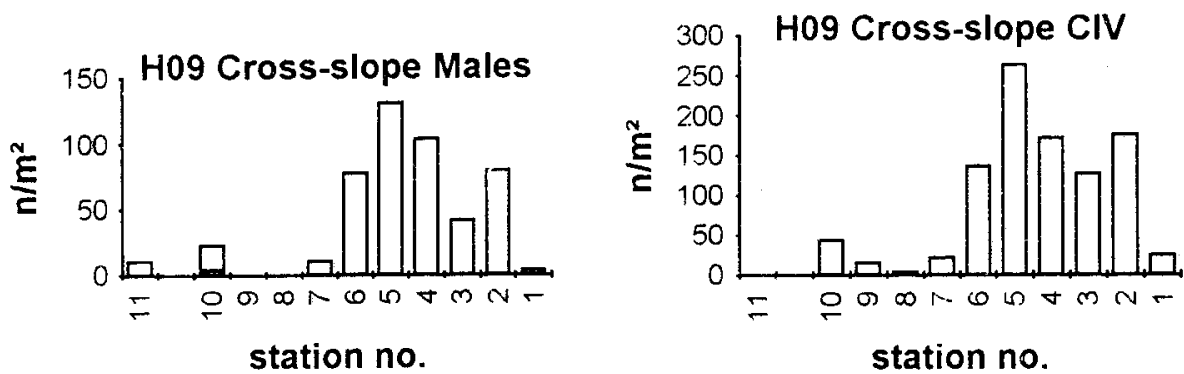

Fig. 12. Numbers of adult and copepodid stages of Calanus helgolandicus in spring 1991 during "Heincke" cruise H09, cross-slope transect, vertical hauls

south $C$. helgolandicus avoids the salinity minimum below $600 \mathrm{~m}$. Within the range of MOW C. helgolandicus occurs deeper. Its depth distribution coincides fairly well with the range of water characterized by $\mathrm{S} \geq 35.6$.

Nearly the whole autumn population and the bulk of the winter population consisted of CV. As in other species of the family Calanidae, the preadult CV stage of C. helgolandicus constitutes the overwintering resting stage, found primarily at a depth of 500-2000 m (Brenning, 1981). However, increasing numbers of adults appear in winter, indicating an early onset of maturation. The abundance maxima were found to have shifted northwards from autumn to winter, while individual numbers were lower by about $70 \%$, both 


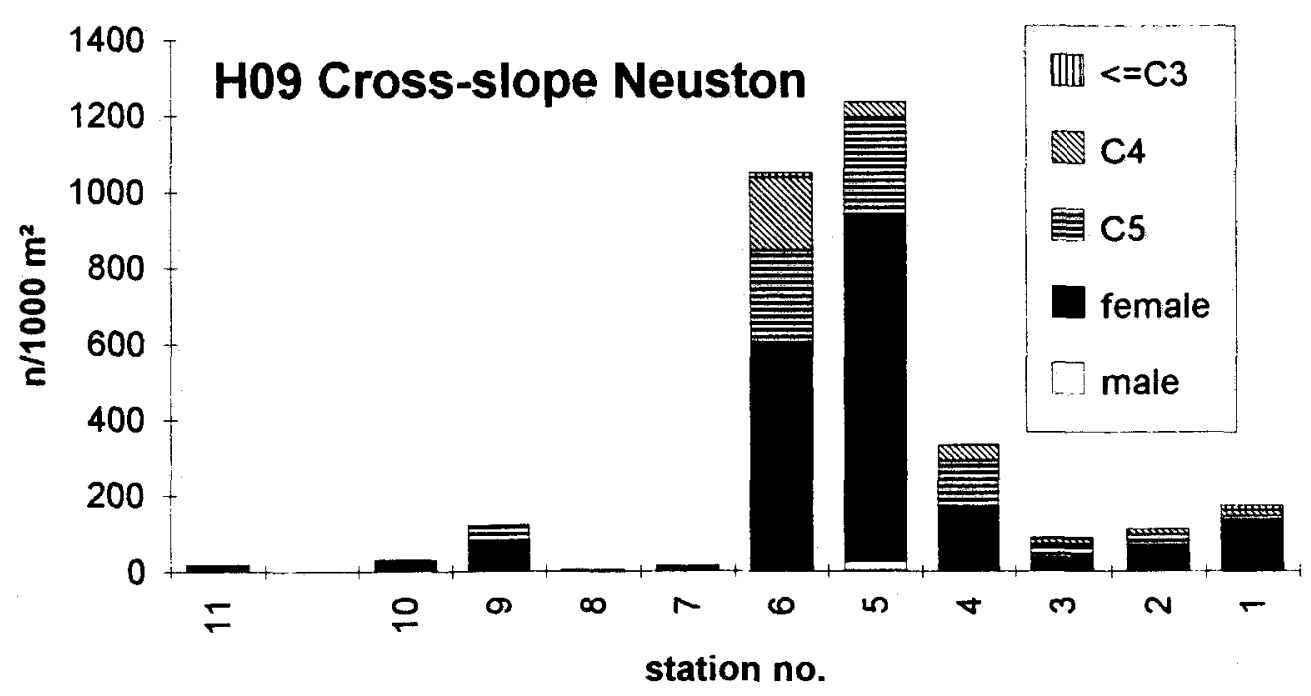

Fig. 13. Surface numbers of adult and copepodid stages of Calanus helgolandicus in spring 1991 during "Heincke" cruise H09, cross-slope transect

suggesting transport of one and the same population by poleward undercurrents. Spring abundances indicate southward transport with surface currents (e.g. the Portugal/Canary Current). The presence of young copepodid stages CIII and CIV indicates that reproduction had taken place prior to the spring survey, possibly at the northernmost stations, because the females showed relatively high abundances even at stations I 4-10.

In spring the $\mathrm{CV}$ consisted probably of individuals of both old and new generation. Their overall condition, recognized by their contents of lipid reserves and the presence of furcal and antennal setae, suggests that CV collected north of station I 13 and probably some of the deeper distributed individuals of stations I $13-15$ belonged to the old, overwintering generation. Fleminger \& Hülsemann (1977) proved the existence of an independent, reproducing population of $C$. helgolandicus in continental waters off N. America. Previously, the Mediterranean was believed to be the centre of dispersal for C. helgolandicus (Conover, 1988). Consequently, individuals found in eastern boundary currents of the Atlantic could have been transported there from the Mediterranean Sea. Williams (1985) described an overwintering population of $C$. helgolandicus in the Celtic Sea and recorded maximum abundances in April/May. According to this author, the $14{ }^{\circ} \mathrm{C}$ thermocline is the northern boundary of the geographical range of $C$. helgolandicus. It appears to be not unlikely that a separate and reproductively active population exists off NW-Africa as well. The numerical contribution of the Mediterranean population by individuals carried into the Atlantic by the outflowing deep water remains unknown. Greze et al. (1985) estimated the plankton biomass carried out of the Mediterranean as being half as high as that carried by the inflowing Atlantic surface water. To confuse matters, our data reveal a pronounced abundance minimum for all stages of C. helgolandicus in autumn and winter within the range of MOW intrusion, which remains largely unexplained. Possibly, the Atlantic plankton was displaced westwards by 
the MOW, which itself may have carried only very limited numbers of $C$. helgolandicus, assuming a similar strategy of resting at greater depths in the Mediterranean.

In the cross-slope transect made in March, maximum abundances of $C$. helgolandicus were found above the continental shelf. Here, females dominated the population, followed by $\mathrm{CV}$, which are presumed to belong to the overwintering generation, judging from their general appearance. This suggests that spawning, hatching, and early development occur primarily in the shallow shelf areas with high phytoplankton productivity. Compared with the isobath-parallel transect, considerably higher numbers of stages younger than $\mathrm{CV}$ were found nearshore, even at the latitude of station I 8, where almost no individuals were recorded offshore. However, the numerical abundance of males was surprisingly low, which probably indicates a more northerly located main mating region. It is suggested that $C$. helgolandicus off northern Portugal prefers the highly productive (upwelling during cruises $\mathrm{H} 09$ and H20) nearshore shelf region for early reproduction, while it migrates offshore farther south (high abundances of CIII at stations I 13-15 in spring). During all cruises, males were extremely rare in the shallowest surface layer, judging by their absence from most of the neuston samples.

The sex ratio for calanid copepods was often suggested to be in favour of females (Green et al., 1993; Kouwenberg, 1993). This seems to be partly due to the sampled depth range, and the geographical region and the season of the surveys. Sampling over the continental shelf may provide results totally different from data obtained offshore, as was demonstrated for the cross-slope cruise (sex ratio 9:1 in favour of females). We assume our data to be largely unbiased and found only slightly higher numbers of females in autumn and spring at the stations of the north-south transect. In contrast to Calanoides carinatus (Stöhr et al., in prep.), males of $C$. helgolandicus did not appear prior to the females and their preference for deeper water strata is only slightly pronounced. Thus, we assume that both species have developed different reproductive strategies. It is generally assumed that males of calanid copepods moult earlier than females in order to use any opportunity to fertilize newly moulted females, thus maximizing their reproductive success (Kouwenberg, 1993). While $C$. carinatus seems to follow this strategy, males of $C$. helgolandicus do not appear to be as short-lived as has often been suggested. In contrast, small numbers of adults seem to moult already during the cold season but do not appear to reproduce until early spring. Overwintering of adults has not been reported previously, therefore it is unknown whether these individuals die without having reproduced or whether they are capable of surviving until spring.

\section{CONCLUSIONS}

Off the Iberian-Moroccan slope a reproductively active population of Calanus helgolandicus exists. Probably, an exchange of individuals between Mediterranean and Atlantic waters occurs to a certain degree. Because the Mediterranean outflow into the E. Atlantic through the Strait of Gibraltar takes place at a depth of 150-300 m as a subsurface current, mostly deeper dwelling older life stages (CIV, CV) may be carried into the Atlantic. Since younger copepodids and most adults prefer layers shallower than $200 \mathrm{~m}$ they are expected to be carried vice versa from the Atlantic into the Mediterranean by the stronger inflow. However, we estimate the number of individuals thus exchanged as being too low to explain alone the high abundance of $C$. helgolandicus found in the 
E. Atlantic, particularly off Morocco. Instead, a stable population is suggested to recirculate within a more or less closed maintenance system by way of southward surface and undercurrents, respectively (Peterson et al., 1979; Wroblewski, 1982; Verheye et al., 1992). In autumn, CV off NW. Africa migrate to the deeper strata below $400 \mathrm{~m}$ and enter a state of dormancy to outlast winter conditions. Then feeding and any activity are reduced to a minimum. In this state they are carried northwards both by means of undercurrents and MOW. When they finally reach northern Portugal in early spring, they rise into the surface layer again, moult, and mature into adults. The relatively high abundances of adults found in the study area during autumn and winter indicate the possibility that adult specimens, too, are capable of overwintering at these latitudes, contrasting previous reports from northern localities. The southern bulk of CV observed in autumn appears to suffer severe reduction on its way north and to represent the winter maximum at the northern stations.

Mating, and possibly reproduction, of $C$. helgolandicus seems to take place in the surface layer of the shelf region. It appears that during maturation young life stages are carried back south with surface currents. Probably, the life cycle is passed through several times - up to 3 times in temperate waters (Conover, 1988); 5-6 times in the Mediterranean during summer (Kouwenberg, 1993), until the southern distributional boundary of this species is reached and the annual cycle completed with the onset of winter conditions, when CV sinks into deeper layers.

Acknowledgements. This survey was funded by the Biologische Anstalt Helgoland, the German Ministry for Research and Technology (grant 03F0050G/H), and the Institute for Remote Sensing of the European Community. E. Hagen (Warnemünde) and E. Mittelstaedt (Hamburg) provided the hydrographical data. Although not directly involved, M. Kloppmann and C. Zelck (Hamburg) contributed continuously to all stages of this project. We thank K. Hülsemann, formerly Biologische Anstalt Helgoland, for her substantial comments on a draft manuscript.

\section{LITERATURE CITED}

Brenning, U., 1981. Beiträge zur Calanoidenfauna (Crustacea, Copepoda) vor Nordwest- und Südwestafrika. I. Die Vertreter der Familie Calanidae. - Wiss. Z. Wilhelm-Pieck-Univ. Rostock 30 (4-5), 1-12.

Conover, R. J., 1988. Comparative life histories in the genera Calanus and Neocalanus in high latitudes of the northern hemisphere. - Hydrobiologia 167-168, 127-142.

Deevey, G. B. \& Brooks, A. L., 1977. Copepods of the Sargasso Sea off Bermuda: Species composition, and vertical and seasonal distribution between the surface and $2000 \mathrm{~m}$. - Bull. mar. Sci. 27, $256-291$

Fleminger, A. \& Hülsemann, K., 1977. Geographical range and taxonomic divergence in North Atlantic Calanus (C. helgolandicus, C. finmarchicus and C. glacialis). - Mar. Biol. 40, 233-248.

Green, E. P., Harris, R. P. \& Duncan, A., 1993. The seasonal abundance of the copepodite stages of Calanus helgolandicus and Pseudocalanus elongatus off Plymouth. - J. mar. biol. Ass. U. K. 73, $109-122$.

Greze, V. N., Kovalev, A. V., Baldina, E. P., Bileva, O. K. \& Shmeleva, A. A., 1985. Zooplankton transfer through the Gibraltar Strait and peculiarities of its taxonomic composition and distribution in adjacent areas. - Investigación pesq. 49, 3-13.

Hempel, G. \& Weikert, H., 1972. The neuston of the subtropical and boreal north-eastern Atlantic Ocean. A review, - Mar. Biol. 13, 70-88.

Kouwenberg, J., 1993. Sex ratio of calanoid copepods in relation to population composition in the northwestern Mediterranean. - Crustaceana 64, 281-299. 
Peterson, W. T., Miller, C. B. \& Hutchinson, A., 1979. Zonation and maintenance of copepod populations in the Oregon upwelling zone. - Deep-Sea Res. (A) 26, 467-494.

Roe, H. S. J., 1972. The vertical distributions and diurnal migrations of calanoid copepods collected on the Sond cruise, 1965. II. Systematic account: Families Calanidae up to and including the Aetideidae. - J. mar. biol. Ass. U. K. 52, 315-343.

Verheye, H. M., Hutchings, L., Huggett, J. A. \& Painting, S. J., 1992. Mesozooplankton dynamics in the Benguela ecosystem, with emphasis on the herbivorous copepods. - S. Afr. J. mar. Sci. 12 , $561-584$.

Weikert, H. \& John, H.-Ch., 1981. Experiences with a multiple opening-closing plankton net. J. Plankt. Res. 3, 167-176.

Williams, R., 1985. Vertical distribution of Calanus finmarchicus and C. helgolandicus in relation to the development of the seasonal thermocline in the Celtic Sea. - Mar. Biol. 86, 145-149.

Williams, R. \& Conway, D. V. P., 1988. Vertical distribution and seasonal numerical abundance of the Calanidae in oceanic waters to the south-west of the British Isles. - Hydrobiologia 167-168, 259-266.

Wroblewski, J. S., 1982. Interaction of currents and vertical migration in maintaining Calanus marshallae in the Oregon upwelling zone - a simulation. - Deep-Sea Res.(A) 29, 665-686. 